\title{
APPLICATION OF Li ION BEAM OBTAINED BY THE CESIUM SPUTTERING SOURCE FOR RBS ANALYSIS OF OPTICAL LAYERS
}

\author{
M. Gaspariūnas, V. Kovalevskij, K. Birzul, A. Plukis, and V. Remeikis \\ Institute of Physics, Center for Physical Sciences and Technology, Savanoriu 231, LT-02300 Vilnius, Lithuania \\ E-mail: mindaugas@ar.fi.lt
}

Received 17 June 2014; revised 5 September 2014; accepted 10 December 2014

\begin{abstract}
High energy $\mathrm{Li}$ ions of multiple charge states $\left(\mathrm{Li}^{+}, \mathrm{Li}^{2+}\right.$ and $\left.\mathrm{Li}^{3+}\right)$ were produced in a tandem accelerator from a source of negative ions by a cesium sputtering (SNICS) ion source. The negative ion current of $\mathrm{Li}$ ions up to $32 \mathrm{nA}$ was obtained in the preacceleration stage after the inflection magnet and retractable aperture. The current of the high energy ion beam obtained after acceleration and used for RBS spectra measurements was up to $3 \mathrm{nA}$. The Li target cone production procedure and design are presented in this work. Initial experiments using Li RBS were performed and their results indicate enhanced analytical application capabilities of RBS for an optical coating analysis, compared to the conventional proton RBS.
\end{abstract}

Keywords: ion beam, accelerator, Cs sputtering, RBS

PACS: $29.25 . \mathrm{Ni}, 82.80 . \mathrm{Yc}$

\section{Introduction}

Rutherford backscattering spectroscopy is widely used to analyse the structure and elemental composition of surface layers of solids [1]. Usually the $\mathrm{He}^{+}$ beam is used for RBS experiments due to relatively good mass and depth resolution [2]. It is known that using the proton beam for RBS increases the analysed depth, but resolution by mass is decreased [3]. The advantages of using ions heavier than $\mathrm{He}^{+}$for the RBS analysis with a noticeable improvement of mass resolution and sensitivity in RBS are well known [ [ E. Norbeck had shown that the distribution of elements as a function of distance from the surface is more clearly revealed with ${ }^{7} \mathrm{Li}$ than ${ }^{4} \mathrm{He}$ [5]. On the other hand, Hiroaki noted that the energy resolution of the detector generally decreases as the projectile mass increases if a silicon surface-barrier detector is used [6]. Possible solution of this problem is the use of higher projectile energy in order to overcome the decrease in energy resolution. The Hiroaki group also used $8 \mathrm{MeV}$ carbon and oxygen ions to improve mass resolution, depth resolution, and sensitivity.

A general Ionex Corporation Model 4110A 1MV accelerator in the Center for Physical Sciences and Technology (CPST) is equipped with a Model $834 \mathrm{Hi}-$ conex Cs ion sputter source [f]. Very low $\mathrm{He}^{-}$yields are reported from cesium sputtering sources [8] and accurate depth profiling requires better mass resolution than proton RBS has to offer. According to M. Mayer [9], the best alternative for the conventional He RBS is to use the lithium ion beam because identical or better depth resolution with $\mathrm{Li}$ than with He can be achieved in the RBS analysis, combined with enhanced mass resolution and sensitivity. It was decided to manufacture a Li target cone for a cesium sputtering ion source for the purpose of improving analytical application of RBS.

One of analytical applications of RBS is quality measurement of optical coatings [10]. The quality of coatings of optical elements is one of the most important issues for any optical system. The proper choice of the type of coatings and their structure gives the possibility to improve parameters of the optical system making light transmission more effective, reducing light reflections and scattering, also suppressing, choosing or transforming light polarization, etc. Development of sophisticated optical coatings includes several important steps: choosing the proper materials, coating design, coating technology, substrates, etc. To obtain the high quality of required optical elements, one must ensure precise thickness, chemical composition and stoichiometry of layers.

\section{Experiment}

Cesium ions in a Hiconex 834 Cs ion sputter source are formed by tungsten surface ionization. Accelerated $\mathrm{Cs}^{+}$ions are used to bombard a cesiated inner surface of a conical target canal lined with the beam 
material [ [7]. Beam ions are sputtered from the surface of the cone by cesium and produce low velocity atoms which charge exchange in the deposited cesium surface layer. Negative ions are extracted from the exit end of the target cone and are accelerated to ground potential, acquiring energy up to $30 \mathrm{keV}$. Twelve target cones may be positioned into the primary beam without breaking vacuum for rapid, convenient change of beam species. Actuation is provided by an air cylinder operating a ratchet and pawl mechanism through bellows. The tandem accelerator is equipped with a gas stripper instead of foils, so the system vacuum during operation is about $2 \times 10^{-5}$ mbar. $\mathrm{N}_{2} 5.0$ gas is used in the tandem gas stripper. The ion current is measured with two Faraday cups: one before the acceleration system and other after the high energy magnet before the measurement chamber. All measurements were done with extraction voltage of $25 \mathrm{kV}$ in the ion source and terminal voltages of $700 \mathrm{kV}$ and $750 \mathrm{kV}$. The terminal voltage is monitored via a voltage divider and the energy of the beam was calibrated using ${ }^{7} \mathrm{Li}(\mathrm{p}, \mathrm{n})^{7} \mathrm{Be}$ nuclear reaction with the $1.881 \mathrm{MeV}$ threshold.

According to R. Middleton and Mayer [8, 9], the most suitable material to produce the $\mathrm{Li}^{-}$ion beam in SNICS is lithium hydroxide, prepared from lithium metal, with the lifetime of 4 to 8 hours depending on the negative ion current. For routinely performed RBS measurements one needs a steady beam producing a target cone with as long lifetime as possible. It was suggested [8] that lithium metal should have the longest cone lifetime, although the beam yield is reported significantly lower $-0.5 \mu \mathrm{A}$. The predrilled titanium cone was used as a support cone for the lithium target (Fig. 11). A $1 \mathrm{~mm}$ thick lithium layer was manufactured by pressing lithium metal into the titanium cone in the Ar atmosphere, then rap-

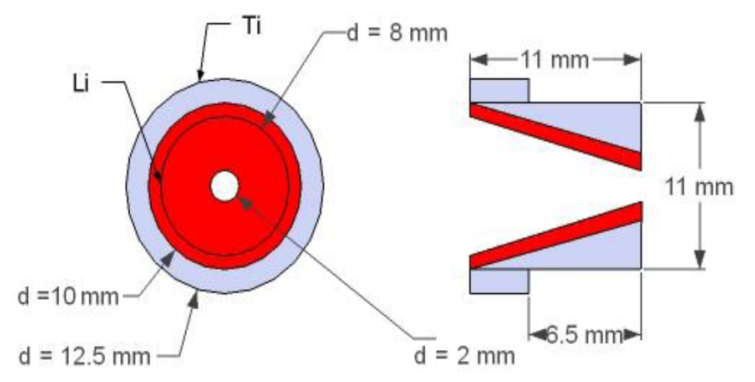

A

B

Fig. 1. The titanium support cone with the pressed in lithium metal layer of $1 \mathrm{~mm}$ thickness. A - top view (beam entrance side), $\mathrm{B}$ - horizontal section profile. idly placed in SNICS and evacuated to the pressure of $2 \times 10^{-5}$ mbar, to avoid oxidation of the lithium surface and of cesium in the SNICS source.

The negative ion current from SNICS is a function of target cone composition, suppressor voltage, cesium ion flux and ionizer power. The rate of cesium vapour flow influences the cesium positive ion current and cesium deposition on the target cone surface [11]. Therefore, the temperature of the cesium reservoir is usually controlled at the optimal level slightly below $180^{\circ} \mathrm{C}$.

Ion mass analysis using the high energy magnet and preliminary results of RBS experiments using the Li beam was performed to confirm and characterize $\mathrm{Li}^{+}, \mathrm{Li}^{2+}$ and $\mathrm{Li}^{3+}$ beams. A collimating aperture of $2 \mathrm{~mm}$ in diameter was placed $10 \mathrm{~cm}$ in front of the target during RBS experiments. A Canberra DSA1000 Multichannel analyzer and an Ortec Model $142 \mathrm{~A}$ preamplifier were used with a surface barrier detector (AMETEK CR-015-050-100, $15 \mathrm{keV}$ alpha resolution) at a scattering angle of $135^{\circ}$ for RBS data acquisition.

The optical coating, manufactured in CPST by ion beam sputtering technique, was selected as the target for initial RBS experiments. Optical layers, consisting of $200 \mathrm{~nm} \mathrm{SiO}_{2}$ on the top of $200 \mathrm{~nm} \mathrm{Nb}_{2} \mathrm{O}_{5}$, were sputtered on the fused silica substrate.

\section{Results and discussion}

Li ion beams were characterized after 8 hours of operation in order to cesiate the inner surface of the conical $\mathrm{Li}$ target. The $\mathrm{Li}^{-}$ion current of $29 \mathrm{nA}$ was obtained with the following parameters of SNICS: ionizer current $28 \mathrm{~A}$, suppressor voltage $4 \mathrm{kV}$, cesium boiler temperature $180^{\circ} \mathrm{C}$ and extraction voltage $25 \mathrm{kV}$. The inflection magnet (bending radius of $59.26 \mathrm{~cm}$ at $30^{\circ}$ ) current was scanned from 0 to $25 \mathrm{~A}$ and the negative ion beam yield from the Li target was measured in the pre-accelerated stage by a Faraday cup after the aperture of $5 \mathrm{~mm}$ in diameter.

Dependence of the negative ion beam current from the Li target on the inflection magnet current is presented in Fig. 2. $\mathrm{H}^{-}, \mathrm{H}^{2-}$ and $\mathrm{H}^{3-}$ peaks can be identified in the recorded spectra at the region of low inflection magnets current. Usually hydrogen gas is sprayed directly on the titanium target cone in SNICS to produce $\mathrm{H}^{-}$beam, so the presence of these peaks can be explained by partial contamination of the $\mathrm{Li}$ cone surface and by the leaking needle-type valve of the hydrogen gas fed system.

The obtained results show that the $\mathrm{Li}^{-}$beam is intensive and well separated from others, therefore being a good choice for further acceleration. $\mathrm{Li}^{2-}$ ion yield 


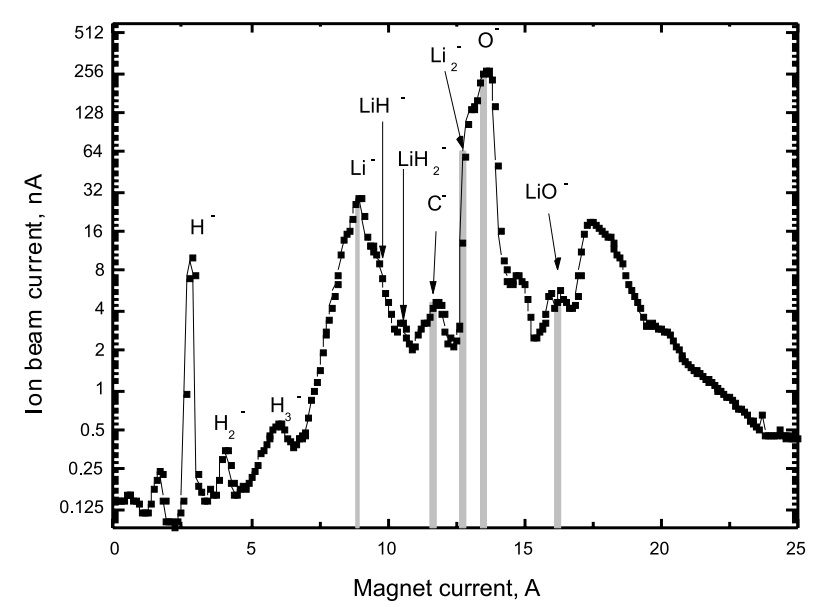

Fig. 2. Negative ion beam current yields from the Li target obtained in the pre-accelerated stage by scanning inflection magnet current. Position of columns indicates the current of the inflection magnet, calculated by Eq. for different mass species: $\mathrm{Li}^{-}, \mathrm{C}^{-}, \mathrm{Li}_{2}^{-}, \mathrm{O}^{-}$and $\mathrm{LiO}^{-}$.

could not be estimated properly due to high intensity of the $\mathrm{O}^{-}$yield and poor mass resolution of the inflection magnet. Moreover, the yield of $\mathrm{Li}^{2-}$ peak is reported more than one order lower than that of $\mathrm{Li}^{-}$[8] in SNICS. Intensity of the $\mathrm{LiO}^{-}$molecular ion was expected to produce low positive ion yields in the accelerated stage, so only the $\mathrm{Li}^{-}$peak was accelerated.

Ion beam yields, obtained by the scanning inflection magnet current, correspond well with other results [8]. Species of ion beam mass was assigned using a relation between kinetic ion energy and magnetic field (bending radius of ion $F_{B}=q v B=m v^{2} / r$ ):

$$
\frac{m}{q}=\frac{B^{2} r^{2}}{2 U}
$$

where $m$ is the mass of accelerated ion, $q$ is the charge state of that ion, $B$ is the magnetic field, $r$ is the bending radius and $U$ is a potential difference for the region of acceleration.

Different positive Li ion charge state yields at different terminal voltage $(700 \mathrm{kV}$ and $750 \mathrm{kV})$ after acceleration are presented in Fig. 3. The Faraday cup measures charge, but not the charge state of the ion. If the ion is ionised more than one time, the current by particles is lower than the current measured by in- duced charge. In this case we have $\mathrm{Li}^{3+} \mathrm{Li}^{2+}$ and $\mathrm{Li}^{+}$ charge states, so the current, measured by the Faraday cup by charge, has to be divided by 3,2 and 1, respectively, to obtain current by particle. The number of incident ions is one of the most important parameters in RBS. Particle current yields of the $\mathrm{Li}^{3+}, \mathrm{Li}^{2+}$ and $\mathrm{Li}^{+}$ charge state at the $700 \mathrm{kV}$ terminal voltage were measured by the second Faraday cup and reached $0.03 \mathrm{nA}$, $0.95 \mathrm{nA}$ and $1.25 \mathrm{nA}$, respectively. This makes $1 \%$, $43 \%$ and $56 \%$ from the total yield of particles for the $\mathrm{Li}^{3+}, \mathrm{Li}^{2+}$ and $\mathrm{Li}^{+}$charge state in the accelerated stage. When the terminal voltage is increased, the yield for higher charge state increases: $2 \%, 49 \%$ and $49 \%$ for $\mathrm{Li}^{3+}, \mathrm{Li}^{2+}$ and $\mathrm{Li}^{+}$ions from the total yield ( $0.07 \mathrm{nA}$, $1.5 \mathrm{nA}$ and $1.48 \mathrm{nA}$ of particle current, respectively). This result corresponds well with the published results in the work of the Kiisk group from Lund University [12]. The $\mathrm{Li}^{3+}$ ion beam would be preferable for RBS experiments due to higher energy, but the intensity of this beam is not sufficient (Fig. 3) to perform RBS experiments, and the penetration depth of $\mathrm{Li}^{-}$ions of $1.5 \mathrm{MeV}$ energy would be too low for a proper analysis of the layer structure.

RBS experiments with optical coating were performed using $\mathrm{H}^{+}(1500 \mathrm{keV})$ and $\mathrm{Li}^{2+}(2800 \mathrm{keV})$ ions beams. In the spectra depicted in Fig. 4, the highest

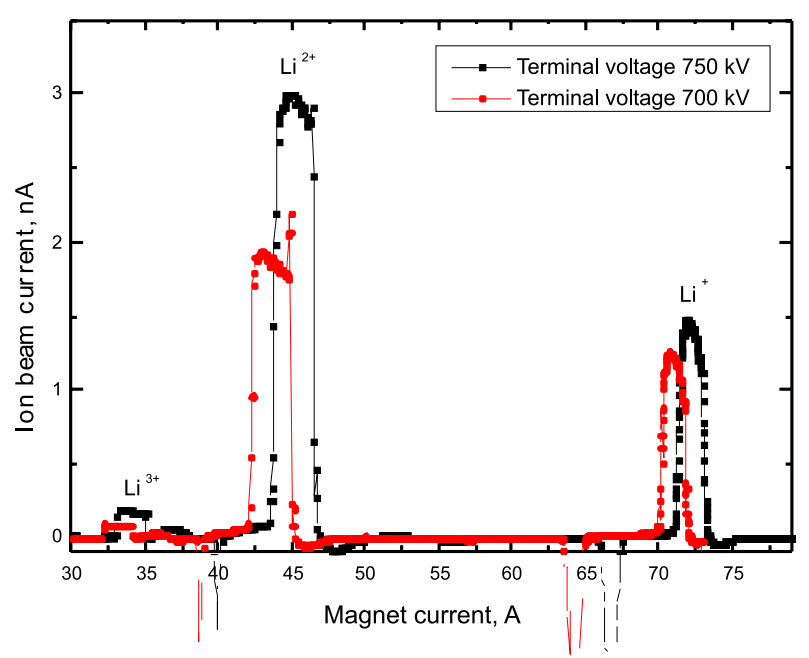

Fig. 3. Positive ion beam yields of different charge state from the Li target, measured by the Faraday cup in the accelerated stage.

Table. Molecular composition of optical layers.

\begin{tabular}{c|c|c|c|c}
\hline Layer & Thickness, $10^{15}$ at $/ \mathrm{cm}^{2}$ & Uncertainty, $10^{15} \mathrm{at} / \mathrm{cm}^{2}$ & $\mathrm{SiO}_{2}$ conc., $\%$ & $\mathrm{Nb}_{2} \mathrm{O}_{5}$ conc., $\%$ \\
\hline 1 & 1570 & 7 & 100 & 0 \\
\hline 2 & 468 & 2 & 37 & 63 \\
\hline 3 & 1896 & 4 & 0 & 100 \\
\hline 4 & Substrate & & 100 & 0 \\
\hline
\end{tabular}




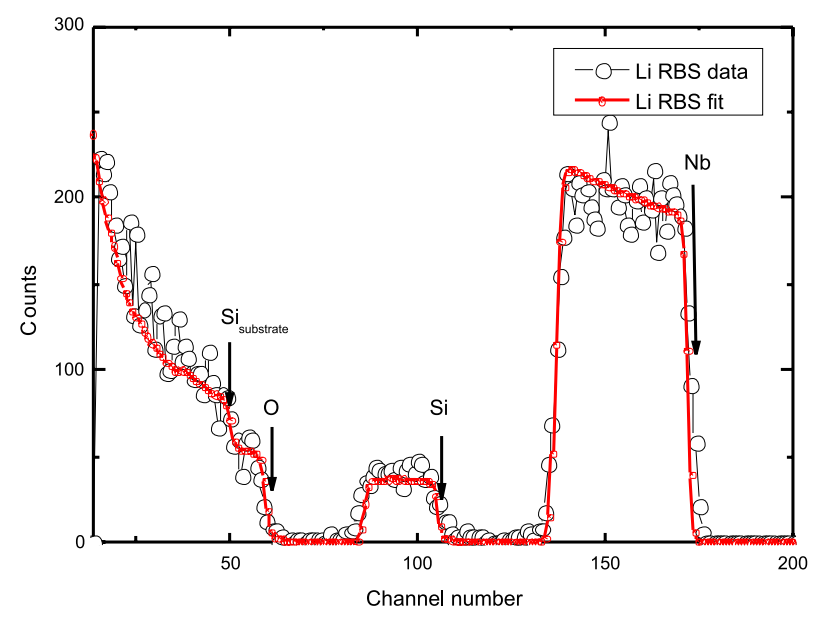

Fig. 4. The backscattered spectrum of the $\mathrm{Li}^{2+}$ ion beam of $2800 \mathrm{keV}$ energy from optical coating and fitting with the DataFurnace code.

backscattered particle energy is recorded from niobi$\mathrm{um}$, the width of the peak is related to the thickness of the layer and the intensity is related to the concentration of the element. Although silicon dioxide is on the surface of the coating, due to lower kinematic factor backscattered particles have lower energy than those from niobium. Only minor difference can be seen in the lower energy part of the spectrum between energies of backscattered particles from oxygen in the coating layer and from silicon in the substrate. Due to multiple scattering and energy straggling in the coating it is difficult to estimate oxygen content in the coating. This is not the case when protons are used (Fig. 5): particles penetrate deeper into the substrate and only high energy part of the spectrum represents niobium, silicon and oxygen from the coating.

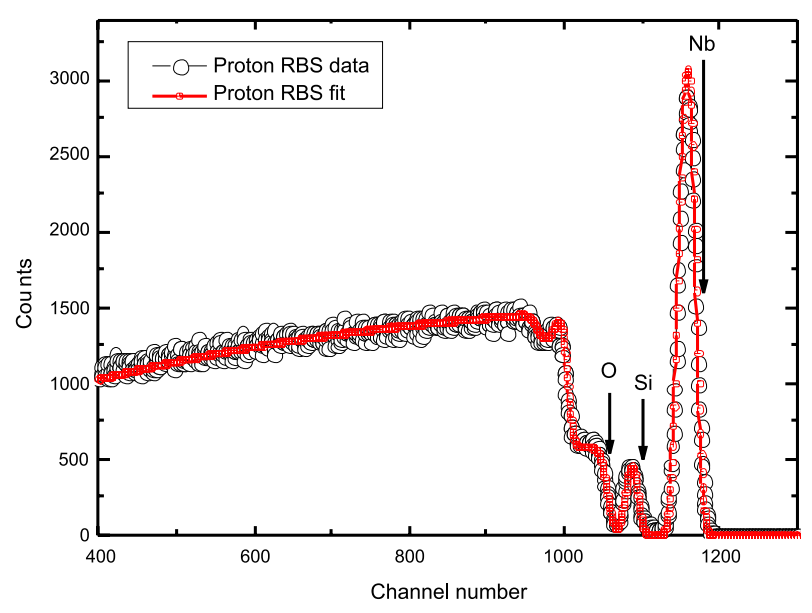

Fig. 5. The backscattered spectrum of the proton beam of $1500 \mathrm{keV}$ energy from optical coating and fitting with the DataFurnace code.
Better mass separation can be seen when comparing the corresponding RBS spectra presented in Figs. 4 and 5. RBS spectra were collected at several $\mathrm{Li}$ ion beam energies: $2175 \mathrm{keV}, 2275 \mathrm{keV}, 2425 \mathrm{keV}$, $2550 \mathrm{keV}, 2675 \mathrm{keV}$ and $2800 \mathrm{keV}$. The collected charge on the sample slightly varied with the increasing terminal voltage and was $120 \mathrm{nC}, 120 \mathrm{nC}, 130 \mathrm{nC}$, $50 \mathrm{nC}, 70 \mathrm{nC}$ and $80 \mathrm{nC}$, respectively, for each energy beam. The DataFurnace ion beam analysis code was used to extract depth profiles from backscattered spectra [13]. By default DataFurnace uses ZBL2000 stopping powers [14]. Depth profiles of irradiated optical coating are presented in Figs. 6 and 7 . Depth profiles in RBS are in $10^{15} \mathrm{at} / \mathrm{cm}^{2}$ units. Values in $\mathrm{nm}$ use weighted averages of atomic densities and are meaningless except for pure layers. To get actual depth in $\mathrm{nm}$, one needs to use different profiling techniques, such as SIMS or profiling with a lateral microbeam.

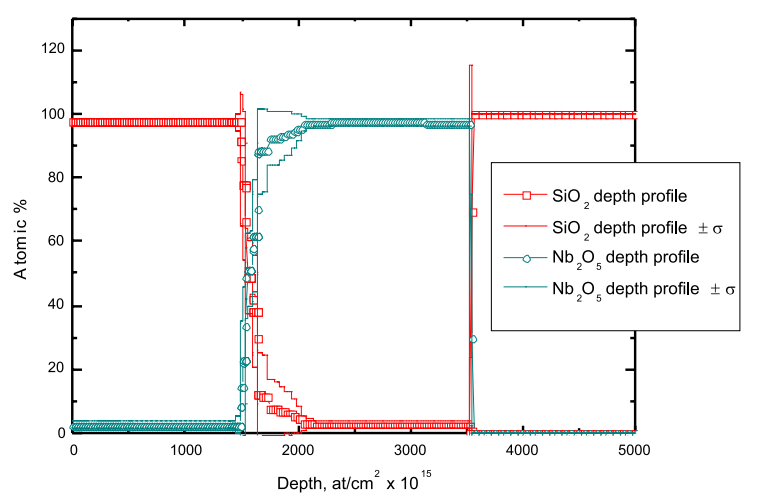

Fig. 6. The depth profile extracted from proton and lithium backscattered spectra with the DataFurnace code. The depicted profiles have uncertainty margins $\pm \sigma$, so the actual structure of layers can be imagined more clearly.

Energy resolution for protons is about $13 \mathrm{keV}$ at $1.5 \mathrm{MeV}$ and for lithium ions it is about $24 \mathrm{keV}$ at the $2.8 \mathrm{MeV}$ energy beam (1.85 times worse than $\mathrm{H}$ resolution). Although energy resolution is decreased almost 2 times when using lithium ions, the overall sensitivity due to better mass resolution increases. The Li ion beam offers better mass separation and surface depth resolution [9]. The maximal beam energy of $\mathrm{Li}^{2+}$ beam $(2800 \mathrm{keV})$ is too low to estimate the oxygen content in the optical coating, but from Fig. 7 it is clear that the niobium content in the optical layer can be estimated with enhanced sensitivity. Analysis of RBS spectra obtained by the proton beam indicates possibility of layer intermixing, which was 


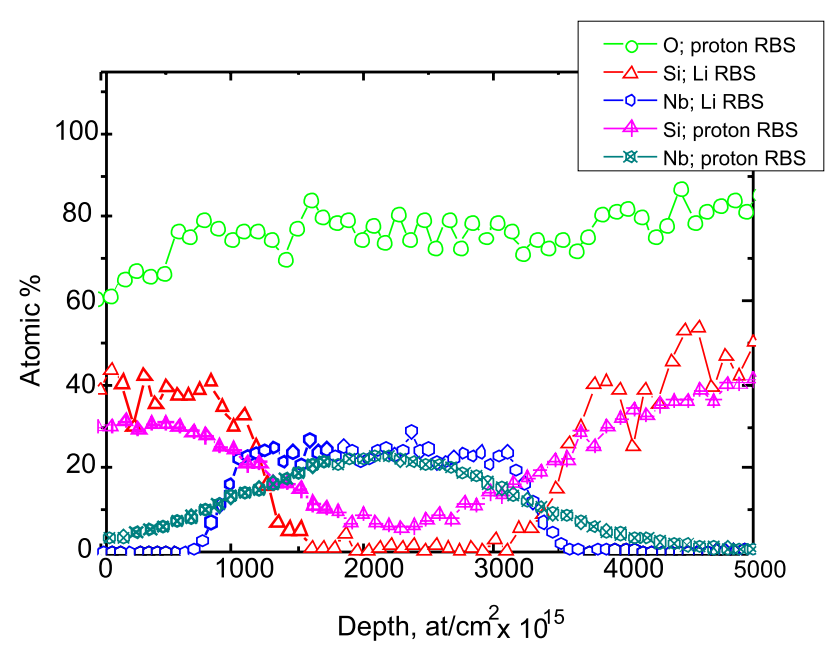

Fig. 7. The elemental depth profile extracted using the DataFurnace code from proton and lithium backscattered spectra separately/independently.

corrected by RBS spectra obtained by the Li beam. Four layers (last of them - fused silica substrate) were assigned to backscattered spectra by simultaneous fitting proton and lithium ion backscattered spectra with the DataFurnace code. Results of the analysis (Fig. 7) still indicate $\mathrm{SiO}_{2}$ and $\mathrm{Nb}_{2} \mathrm{O}_{5}$ intermixing in the second layer of $46810^{15} \mathrm{at} / \mathrm{cm}^{2}$ thickness, but the $+\sigma$ profile of $\mathrm{SiO}_{2}$ and the $-\sigma$ profile of $\mathrm{Nb}_{2} \mathrm{O}_{5}$ are without layer intermixing. The composition of the optical coating is presented in the Table.

\section{Conclusions}

$\mathrm{Li}^{-}$ions were successfully extracted from the Cs sputtering source and different charge state $\left(\mathrm{Li}^{+}, \mathrm{Li}^{2+}, \mathrm{Li}^{3+}\right)$ of the positive Li ion beam was obtained after acceleration in a Tandetron $4110 \mathrm{~A}$ accelerator. The most intensive $\mathrm{Li}^{2+}$ beam current reached up to $3 \mathrm{nA}$ and was chosen to perform initial Li RBS experiments. The yield of the $\mathrm{Li}^{2+}$ ion beam was sufficient enough to estimate thicknesses of optical layers with enhanced precision, but not enough to eliminate uncertainties in the evaluation of elemental profiles of the optical coating. The performed analysis of RBS spectra shows that $\mathrm{Nb}_{2} \mathrm{O}_{5}$ layer intermixing with $\mathrm{SiO}_{2}$ is doubtful within the margins of the error $( \pm \sigma)$. Although energy resolution of the surface barrier detector for Li ions is worse than for protons, overall analytical application of RBS was improved due to better mass resolution, offered by the Li beam and simultaneous experimental data treatment with the DataFurnace code. Combined ion beam analysis using proton and Li produced in SNICS sources are viable alternatives to the helium ion beam that requires a duoplasmatron type source.

\section{Acknowledgements}

Authors of this work would like to thank Dr. Rytis Buzelis and Ph. D. student Simonas Kičas for their contribution to this work by providing optical coating as a sample for RBS experiments.

\section{References}

[1] H.R. Verma, Atomic and Nuclear Analytical Methods (Springer, Berlin, 2008).

[2] C.J. Tavares, L. Rebouta, E. Alvesb, N.P. Barradas, J. Pacaudd, and J.P. Riviere, Study of roughness in $\mathrm{Ti}$ 0.4Al 0.6N/Mo multilayer structures, Nucl. Instrum. Methods B 188, 90-95 (2002).

[3] M. Tosaki, S. Ito, and N. Maeda, Detailed analysis of the resonant backscattering spectrum for deeply penetrating protons in carbon, Nucl. Instrum. Methods B 168, 543-552 (2000).

[4] J.R. Liu, Z.S. Zheng, Z.H. Zhang, and W.K. Chu, RBS and ERD analysis using lithium ions, Nucl. Instrum. Methods B 85, 51-54 (1994).

[5] E. Norbeck, L.W. Li, H.H. Lin, and M.E. Anderson, Rutherford backscattering (RBS) with lithium ions, Nucl. Instrum. Methods B 9, 197-200 (1985).

[6] H. Niwa, S. Nakao, and K. Saitoh, Application of heavy-ion RBS to compositional analysis of thin films, Nucl. Instrum. Methods B 136-138, $297-$ 300 (1998).

[7] General Ionex Corporation, Tandetron Analyzer, Model 4110A, Instruction Manual, 791201-RBL/ CJR.

[8] R. Middleton, A Negative-Ion Cookbook (Philadelphia, PA, 1990).

[9] M. Mayer, J. Roth, and K. Ertl, Rutherford backscattering spectroscopy and elastic recoil detection analysis with lithium ions - The better alternative to helium? Nucl. Instrum. Methods B 190, 405409 (2002).

[10] G. Abromavicius, R. Buzelis, R. Drazdys, K. Juškevičius, S. Kičas, T. Tolenis, J. Mirauskas, M. Ščiuka, V. Sirutkaitis, and A. Melninkaitis, Optical resistance and spectral properties of antireflective coatings deposited on LBO crystals by ion beam sputtering, Lith. J. Phys. 51(4), 303-308 (2011).

[11]X.M. Wang, J.R. Liu, L. Shao, K.B. Ma, H. Chen, X.K. Yu, and W.K. Chu, Extraction of $\mathrm{SiN}^{-}$ions from source of negative ions by cesium sputtering, Nucl. Instrum. Methods B 241, 885-889 (2005).

[12] M. Kiisk, R. Hellborg, P. Persson, M. Faarinen, G. Skog, and K. Stenstrom, The charge state distribution of $\mathrm{Be}, \mathrm{C}, \mathrm{Cl}$ and $\mathrm{Al}$ ions at the Lund Pelletron accelerator with the recently modified terminal pumping in use, Nucl. Instrum. Methods A 521, 299-305 (2004). 
[13] N.P. Barradas and C. Jeynes, Advanced physics and algorithms in the IBA DataFurnace, Nucl. Instrum. Methods B 266, 1875-1879 (2008).
[14]J.F. Ziegler, M.D. Ziegler, and J.P. Biersack, SRIM - The stopping and range of ions in matter, Nucl. Instrum. Methods B 268, 1818-1823 (2010).

\title{
CEZIO DULKINIMO ŠALTINYJE IŠGAUTO Li JONŲ PLUOŠTELIO PANAUDOJIMAS OPTINIŲ DANGŲ RBS ANALIZEI
}

\author{
M. Gaspariūnas, V. Kovalevskij, K. Birzul, A. Plukis, V. Remeikis \\ Fiziniu ir technologijos mokslu centro Fizikos institutas, Vilnius, Lithuania
}

\section{Santrauka}

Kietujų kūnų paviršių analizei gali būti naudojama Rezerfordo atgalinès sklaidos spektroskopija (RBS). Tandemo tipo dalelių greitintuvuose, kurie komplektuojami su neigiamų jonų cezio dulkinimo šaltiniais, iprastai tokiems tyrimams naudojamo $\mathrm{He}^{-}$pluoštelio išeiga yra labai maža. Norint praplèsti protonų RBS analitines galimybes, neigiamų jonų šaltinyje išgautas $\mathrm{Li}^{-}$jonų srautas, kurio srove sieke $32 \mathrm{nA}$. Greitinant $\mathrm{Li}^{-}$jonus, užregistruotos visos galimos teigiamos ličio jonų krūvio būsenos $\left(\mathrm{Li}^{+}, \mathrm{Li}^{2+}, \mathrm{Li}^{3+}\right)$. Atsižvelgiant $\mathfrak{i}$ skirtingų būsenų igreitintų jonų srovę bei dalelès siekị medžiagoje, RBS eksperimentams atlikti buvo pasirinktas $\mathrm{Li}^{2+}$ srautas ir ištirta jonapluoščio dulkinimo būdu suformuota danga, sudaryta iš $200 \mathrm{~nm} \mathrm{SiO}$ ir
$200 \mathrm{~nm} \mathrm{Nb} \mathrm{O}_{5}$ sluoksnių, užgarintų ant amorfinio silicio padéklo. Nors detektoriaus energijos skyra naudojant Li pluoštelị suprastejja iki $24 \mathrm{keV}$, palyginti su $13 \mathrm{keV}$, kai naudojamas protonų pluoštelis, tačiau dèl geresnès masių skyros pasiekiami tikslesni rezultatai: niobio ir silicio elementiniai profiliai dangoje atskiriami aiškiau. Gautu $\mathrm{Li}^{2+}$ jonu daleliu srautas pakankamai intensyvus dangoje esančiu sluoksnių storiams bei jų stechiometrijai nustatyti, tačiau nepakankamas elementinių profilių vertinimo paklaidoms sumažinti. $\mathrm{SiO}_{2}$ ir $\mathrm{Nb}_{2} \mathrm{O}_{5}$ sluoksnių persiklojimas mažai tikètinas dèl persiklojančių paklaidų $( \pm \sigma)$. Naudojant DataFurnace jonų analizès programini paketą, galima apjungti protonų bei ličio jonų RBS eksperimentus ir taip tiksliau ịvertinti tiriamų objektų paviršinę sandarą. 